\title{
Algorithm of Ecocompensation in Sloping Land Conversion Program Based on Heckman's Two-Step Model
}

\author{
Haotian Wang $\mathbb{D},{ }^{1}$ Chen $K e \mathbb{D},{ }^{1}$ and Xiaojun Yang $\mathbb{D}^{2}$ \\ ${ }^{1}$ Shenyang Agricultural University, Shenyang, Liaoning 110866, China \\ ${ }^{2}$ School of Public Policy and Administration, Xi'an Jiaotong University, Xi'an, Shaanxi 710049, China \\ Correspondence should be addressed to Haotian Wang; wangyucheng0107@126.com
}

Received 16 September 2021; Revised 12 October 2021; Accepted 19 October 2021; Published 24 November 2021

Academic Editor: Punit Gupta

Copyright $(92021$ Haotian Wang et al. This is an open access article distributed under the Creative Commons Attribution License, which permits unrestricted use, distribution, and reproduction in any medium, provided the original work is properly cited.

In this paper, we broadly generalize the assignment auction algorithm to solve linear minimum cost network flow problems. It is significant to establish a market-based compensation mechanism by way of conservation auctions based on peasant households' willingness, which can promote the innovation of ecocompensation policies, green development, and balanced growth. Using the survey data collected from 453 households within 3 national pilot counties in ecologically fragile regions in northwest Liaoning for the Sloping Land Conversion Programme, measuring peasant households' willingness to accept ecocompensation through sealed auctions, we built a database through cloud computing to realize information collation and query and applied the Heckman's Two-Step Model to study the impact of risk preference, social capital, cognitive preference, land parcel characteristics, and family endowments on farmers' willingness to participate in protection auctions and their bid prices. The results reveal that the average bid price of peasant households in the ecologically fragile region in northwest Liaoning for the Sloping Land Conversion Programme is annually 274.5 yuan per mu and that risk preference and social capital have positive impacts on peasant households' willingness to participate in conservation auctions and on their bid prices, cognitive preference has a positive impact on peasant households' bid prices in conservation auctions, and land plot characteristics have a negative impact on peasant households' bid prices in conservation auctions. It is suggested that ecocompensation policies should be optimized with such methods as lowering peasant households' perception of high risks, setting role models for them to follow, and strengthening their perception of the environment, income, and property rights.

\section{Introduction}

Ecocompensation is a willingness-based transaction mechanism, where ecosystem service (ES) buyers/users/beneficiaries make direct and contractually agreed payments to ES providers [1]. Payment standards that influence incentive effects are always the core of policy design [2]. As a landmark project in the course of China's ecological conservation, research on ecocompensation standards for the Sloping Land Conversion Programme (SLCP) made by scholars with the ES value method $[3,4]$, contingent valuation method (CVM) [5, 6], choice experiment method (CE) [7], and opportunity cost approach (OCA) $[8,9]$ has been running through all the phases of programme implementation. Nondiscriminatory compensation standards based on opportunity costs for the SLCP have the advantages of openness, transparency, and easy operation, but they also have the problem of information asymmetry between ES providers and users [2], which leads to either insufficient compensations lower than ES providers' opportunity costs or inefficient overcompensation transactions. What is worse, recultivation in major grain producing areas and reclamation in barren areas occur even more frequently due to hidden action caused by moral hazard [10].

In order to reduce informational rents generated by heterogeneity in opportunity costs, Ferraro proposed three solutions: gathering information relevant to opportunity costs, revealing peasant types by screening contracts, and using conservation auctions [11]. As an effective marketbased policy tool, the mechanism of conservation auction 
allows ES providers to express their opportunity costs actively through specific mechanism desig, and ultimately improve ES programs' fund use efficiency [12].

The mechanism of conservation auction was first used in ecocompensation practices in developed countries, including the BushTender Trial (BTT) in Australia and the Conservation Reserve Program (CRP) in the United States $[13,14]$. Several cases of peasant households' participation in conservation auctions were also found in developing countries such as Indonesia, Malawi, and Kenya [15-17]. Thereafter, a few scholars in China started their research on conservation auctions [18-20].

An overview of key theoretical and laboratory studies on the mechanism of conservation auction by scholars at home and abroad reveals three problems that are worth noticing. First, there is a lack of theoretical research to reveal ES providers' opportunity costs. Second, there is currently little relevant research on unobservable factors featuring heterogeneity in ES providers [21]. Third, it still needs to be verified whether the mechanism of conservation auction can be used as an effective policy tool to solve environmental issues in developing countries.

To bridge the existing research gaps summarized above, this article takes the Sloping Land Conversion Programme, one of the biggest ecocompensation programs in the world at present, as an example to reveal peasant households' real opportunity costs through the mechanism of conservation auction, which is expected to provide a valuable reference for China's innovation of ecocompensation policies and its establishment of a long-term effective ecocompensation mechanism.

What makes this research innovative primarily lies in three aspects. First, the opportunity costs offered by peasant households for plots of land were taken as an essential indicator of ES provider heterogeneity to examine how peasant households' opportunity costs affect their participation in conservation auctions, which lays a foundation for the establishment of discriminatory ecocompensation standards. Second, based on Heckman's Two-Step Model, we study the impacts of unobservable factors including risk preference, cognitive preference, and social capital on peasant households' willingness to participate in conservation auctions, which is also innovative to some extent. Third, our study on SLCP ecocompensation with the conservation auction mechanism expands the range of applying the conservation auction mechanism in developing countries.

\section{Research Design}

2.1. Theories and Hypotheses. In 1997, Latacz-Lohmann and Van der Hamsvoort developed a hypothetical program to verify that the conservation auction mechanism can significantly promote the program's cost-effectiveness [12]. They concluded that an ES provider's bid price is formed based on a balance between net income and the probability of winning the bid, that the tender decision is made on the basis of the ES provider's expectation on the highest price acceptable to the government, and that the optimal bid price is the one that maximizes the expected utility or gain from the auction. Existing findings disclose several individual characteristics that affect an ES provider's tender decision, including his age, race, education, residence, etc. [21].

Risk preference is a key factor affecting SLCP peasant households' decision-making behavior [22]. When examining the issue of risk difference, Latacz-Lohmann and Van der Hamsvoort divided peasant bidders into two types: risk neutral and risk averse, arguing that risk averse bidders tend to lower their bids to increase the probability of winning the bid [12]. In reality, ES providers represented by peasant households are mostly the risk averse type, and there are even highly risk averse peasant households who refuse to participate in conservation auctions [23]. Cognitive preference also has impacts on SLCP peasant households [24]. When bidding in conservation auctions, those with relatively higher levels of environmental perception know better the importance of ecological services and therefore tend to increase their tender prices to earn informational rent [25]. According to The Rational Peasant by Schultz [26], peasant households' decision-making behavior is profit-driven, and the bid prices offered by peasant households in conservation auctions are positively correlated with their perception of income. As an important means to make external and public goods become internal and private, clarification of property rights is of positive significance to promote peasant households' management and conservation of natural resources [27]. Influenced by the endowment effect, peasant households having a better perception of property rights tend to offer higher tender prices [28]. As a sort of group characteristic, behavior, or outcome, social capital affects individual behavior or outcome [29]. Whether an individual possesses social capital or not decides his amount of right to speak or to make decisions. Therefore, participants with rich social capital tend to be in a more advantageous position in conservation auctions [30, 31]. Land is the most important means of production for peasant households, and plots of land are basic units for the SLCP. Peasant households make their bids based on the opportunity costs of land plots [25]. They tend to offer higher bid prices for good-quality land plots with higher opportunity costs. In this article, four hypotheses are summed up and proposed as follows:

$\mathrm{H}_{1}$ : peasant households' bid prices are positively correlated with their risk preference

$\mathrm{H}_{2 \mathrm{a}}$ : peasant households' bid prices are positively correlated with their perception of the environment

$\mathrm{H}_{2 \mathrm{~b}}$ : peasant households' bid prices are positively correlated with their perception of income

$\mathrm{H}_{2 \mathrm{c}}$ : peasant households' bid prices are positively correlated with their perception of property rights

$\mathrm{H}_{3}$ : peasant households' bid prices are positively correlated with the social capital they own

$\mathrm{H}_{4}$ : peasant households' bid prices are positively correlated with the opportunity costs of their land plots

2.2. Data Sources. The Sloping Land Conversion Program is a major policy decision made by China to improve the ecological environment and build an ecological civilization 
[32]. As one of the top ecologically sensitive zones in China, the ecologically fragile region in northwest Liaoning has finished one-fifth of Liaoning Province's SLCP work in the first round. The data of this article are sourced from the field survey made by the research team between 2019 and 2020 in 3 national SLCP pilot counties in the ecologically fragile region in northwest Liaoning, namely, Zhangwu, Beipiao, and Jianchang, involving 18 villages 6 townships. With the method of stratified sampling, the research team first selected 2 townships at random from each county and then selected 3 villages from each township at random for the survey. Ultimately, 480 households who participated in the first round of the SLCP were drawn as samples, and finally 453 valid questionnaires were sorted out, accounting for $94.4 \%$

2.3. Research Design. How conservation auctions are designed directly affects the effect of implementing the SLCP, which is supposed to reveal peasant bidders' real opportunity costs and avoid possible moral hazard caused by fraud [33]. Referring to the study by Han Hongyun and $\mathrm{Yu}$ Yonghong [7], this research is designed to adopt a sealed bid procurement auction to give peasant households continuous compensation for the SLCP. The use of a single-round auction permits a direct observation of the field experiment results of the conservation auction, which helps relieve participants' tiredness and cognitive load in the survey and meanwhile reduce the management and transaction costs of the auction $[34,35]$. Auction payment rules mainly include discriminatory price auctions and uniform price auctions. Discriminatory pricing is closer to bidders' real costs, and its cost-effectiveness performs better on the whole [36, 37]. Before each auction, the researchers explain in detail the auction process to avoid abnormal bidders. The auction design in this article is shown in Table 1.

\subsection{Research Methodology}

2.4.1. Query of Farmers' Bidding Information under Cloud Computing. According to the bidding information resources, cloud computing technology is used to divide the integrated information resources into multiple subsets according to the attributes of the information relationship. After the division is completed, the database construction is completed in a bottom-up manner.

Adopt SQL SERVER 2000 database management system, call the distributed information integration function in the database, and coordinate the management of the database through cloud computing technology. Design four query methods:

(1) Uncertain query: In the database, there are two types. One is that the query information is stored on a certain node. When the word "query completed" appears, the query ends; the other is that the query information is stored on multiple nodes. Based on the first query, I want to continue to query and obtain information.
(2) Combined query: Divide the query information in more detail, and define query $D$ as shown in the following formula:

$$
D=d_{1} \cup d_{2} \cup \cdots \cup d_{n} .
$$

In the formula, $d_{1}, d_{2}, \ldots d_{n}$ represent atomic queries. Atomic query is to store all query results on a node, that is, to obtain the data at that point.

(3) Connect query: the connection query in the database is divided into two connection queries and multiple connection queries. In the first type, two connection queries, the query information is defined as follows:

$$
D=d_{1} \propto d_{2} \text {. }
$$

In the formula, $\infty$ represents the connection symbol. There are three query results shown in the following formula:

$T D \approx T d_{1} \approx T d_{2}$ or $T D \approx T d_{1}$ and $T D>T d_{2}$.

In the formula, $T$ represents the record information; $T D, T d_{1}$, and $T d_{2}$, respectively, represent the record number of $D, d_{1}$, and $d_{2}$. The second is multiconnection query; the query information is defined as follows:

$$
D=d_{1} \propto d_{2} \propto \cdots \infty d_{n} .
$$

Reduce the redundant data in the database; at the same time, connect the atomic query with the node to complete the information query.

(4) Compound query: The composite result of the merge and join query is shown in the following formula:

$$
D=F\left(d_{1}, d_{2}, \cdots, d_{n}\right) \text {. }
$$

In the formula, $F$ represents the function composed of $\infty$ and $U$.

After completing the above steps, the database construction and information query can be realized.

2.4.2. Peasant Household Bidding Model. Supposing there are $N$ peasant households participating in the government's compensation for the SLCP, the bid price and opportunity cost of Peasant Household $i$ are, respectively, $b_{i}$ and $\delta_{i}$. Then, the objective function and the optimal strategy of Peasant Household $i$ in the discriminatory auction are summed up as follows.

The objective function of Peasant Household $i$ is

$$
\max _{b_{i}} \prod_{i}=\left(b_{i}-\delta_{i}\right) E_{i}\left[P\left(b_{i} \leq b_{n}\right)\right] .
$$

The optimal strategy of Peasant Household $i$ is

$$
b_{i}^{*}=\delta_{i}-\frac{E_{i}\left[P\left(b_{i} \leq b_{n}\right)\right]}{\partial E_{i}\left[P\left(b_{i} \leq b_{n}\right)\right] /\left.\partial b_{i}\right|_{b_{i}=b_{i}^{*}}} .
$$


TABLE 1: Design of conservation auction.

\begin{tabular}{|c|c|}
\hline Payment type & Discriminatory auction \\
\hline Bid setting & A reserve price is set \\
\hline Auction type & Sealed bid procurement auction \\
\hline Auction budget & Unknown \\
\hline Auction rounds & 1 round (a trial before the formal experiment) \\
\hline Number of bidders & Fixed \\
\hline Bid unit & $1 \mathrm{mu}$ \\
\hline $\begin{array}{l}\text { Decision-making } \\
\text { environment }\end{array}$ & $\begin{array}{c}\text { Peasant households make individual decisions in their own places of residence, without any exchange of other } \\
\text { information between households during the whole decision-making process }\end{array}$ \\
\hline
\end{tabular}

2.4.3. Heckman's Two-Step Model: The Mechanism Affecting Peasant Households' Bid Decision-Making. Referring to relevant research on Heckman's Two-Step Model [38], the current study divides peasant households' bid decisionmaking process into two steps in the current study. The first step is that peasant households make decisions on whether to participate in bidding and their willingness to do that is defined as a binary choice variable between 0 and 1 ; the second step is that peasant households who are willing to participate in bidding make decisions on their bid price, which is a continuous variable. The model is set as follows:

$$
\begin{aligned}
& Z_{i}= \begin{cases}0, & Z_{i}^{*} \leq 0, \\
1, & Z_{i}^{*}>0,\end{cases} \\
& Z_{i}=a_{0}+a_{1} X_{i}+a_{2} C_{i}+a_{3} D_{i}+\varepsilon_{i}, \\
& Y_{i}=b_{0}+b_{1} X_{i}+b_{2} C_{i}+b_{3} \lambda+\mu_{i} \begin{cases}\text { unobservable, } & Z_{i}=0, \\
\text { observable, } & Z_{i}=1 .\end{cases}
\end{aligned}
$$

Formulas (1) and (2) constitute the selection model for Heckman's first step, and formula (3) is the result model of Heckman's second step. In formula (1), $Z_{i}^{*}$ is the latent variable of peasant households' willingness to bid. If $Z_{i}^{*} \leq 0$, then $Z_{i}=0$; otherwise, $Z_{i}=1$. In formula (2), $X_{i}$ is the core explanatory variable affecting peasant households' bidding, $C_{i}$ is the control variable, $D_{i}$ is the identification variable, and $\varepsilon_{i}$ is the error term. In formula (3), $Y_{i}$ is the peasant household's bid price, $\lambda$ is the inverse Mills ratio, and $\mu_{i}$ is the error term.

2.5. Variable Selection. In accordance with the research objectives, a peasant household's willingness to bid and bid price are chosen as explained variables, while a peasant household's risk preference, social capital, cognitive preference, and land plot characteristics are chosen as the core explanatory variables. According to theoretical research on behavioral economics, a peasant household's risk preference can be measured directly [39]. In this research, 2 indicators of risk preference, namely, planting risk and investment risk, are selected through combining the management characteristics of peasant households involved in the SLCP. Referring to the study made by Liao Peiling and other scholars [40], perception of the environment, perception of income, and perception of property rights are selected as 3 indicators of cognitive preference.
Based on the research by Lv Qian and Wang Xin [41], social prestige, social network, and social participation are selected as 3 indicators of social capital. Referring to the proxy variables of ES opportunity costs proposed by Kosoy and other scholars [42], taking the ecological and economic benefits of a land plot into account, quality of the land plot, income of the land plot before conversion, and slop of the land plot are selected as 3 indicators of land plot characteristics. Control variables include low-income households, age of the head of household, health status of the head of household, education of the head of household, political status of the head of household, household labour, per capita annual income of household, proportion of the SLCP income, area of arable land, and area of converted land. According to the requirement of Heckman's Two-Step Model, identification variables should be chosen from the conditions that have significant impacts on willingness to bid but insignificant impacts on bid prices. To this end, proportion of SLCP peasant households in the village is selected as the identification variable due to two considerations: on one hand, peasant households are more likely to participate in conservation auction when there are higher proportion SLCP peasant households in the village; on the other hand, the proportion of SLCP peasant households in the village could not be likely affecting the individual peasant household's bid prices. The variables description and descriptive statistics are shown in Table 2.

\section{Results and Analysis}

3.1. Analysis of Results. Per capita income of household and income of the land plot before conversion are processed with logarithm to eliminate errors. Then, due to VIF, the two variables, income of the land plot before conversion (after logarithm) and soil quality, fail the test for multicollinearity. The first step is to construct the Probit regression model and calculate the inverse Mills ratio $\lambda$; the second step is to put the inverse Mills ratio $\lambda$ into the least squares regression model with bid price as the dependent variable. The results show that the inverse Mills ratio $\lambda$ is statistically significant at the $10 \%$ level, which implies sample selection bias exists and Heckman's Two-Step Model is applicable. Pseudo- $\mathrm{R}^{2}$ of the Probit model is 0.424 , and $\mathrm{R}^{2}$ of the OLS model is 0.505 , which indicates a good fit between the two models. Results of the two regression models are shown in Table 3.

The estimated results of Heckman sample selection model are summarized as follows: 
TABle 2: Variable description and descriptive statistics.

\begin{tabular}{|c|c|c|c|c|c|}
\hline Variables & Variable definition and description & Mean & $\begin{array}{l}\text { Standard } \\
\text { deviation }\end{array}$ & Minimum & Maximum \\
\hline \multicolumn{6}{|l|}{ Explained variables } \\
\hline \multirow{2}{*}{$\begin{array}{l}\text { Peasant household's } \\
\text { willingness to bid } \\
\text { Peasant household's bid } \\
\text { price }\end{array}$} & $\begin{array}{c}0=\text { unwilling to participate in bidding; } 1=\text { willing to } \\
\text { participate in bidding }\end{array}$ & 0.786 & 0.411 & 0 & 1 \\
\hline & Peasant household's bid price (yuan/mu) & 274.535 & 125.824 & 50 & 650 \\
\hline \multicolumn{6}{|l|}{$\begin{array}{l}\text { Core explanatory variables } \\
\text { Risk preference }\end{array}$} \\
\hline Planting rick & $\begin{array}{c}\text { Willingness to plant new varieties of crops: very } \\
\text { unwilling }=1 \text {, unwilling }=2 \text {, no opinion }=3 \text {, willing }=4 \text {, very } \\
\text { willing }=5\end{array}$ & 2.980 & 1.359 & 1 & 5 \\
\hline Investment risk & $\begin{array}{c}\text { Willingness to make high-risk investments: very } \\
\text { unwilling }=1 \text {, unwilling }=2 \text {, no opinion }=3 \text {, willing }=4 \text {, very } \\
\text { willing }=5\end{array}$ & 2.459 & 1.223 & 1 & 5 \\
\hline \multicolumn{6}{|l|}{ Social capital } \\
\hline Social prestige & Is there any village cadre in the household: yes $=1$, no $=0$ & 0.099 & 0.299 & 0 & 1 \\
\hline Social network & $\begin{array}{l}\text { Number of relatives in the village (households): } 0 \sim 5=1 \text {, } \\
\qquad 5 \sim 10=2,10 \sim 15=3,15 \sim 20=4,>20=5\end{array}$ & 2.402 & 1.538 & 1 & 5 \\
\hline Social participation & $\begin{array}{l}\text { Participation in village affairs: seldom }=1 \text {, occasionally }=2 \text {, } \\
\text { sometimes }=3 \text {, often }=4 \text {, always }=5\end{array}$ & 2.461 & 1.190 & 1 & 5 \\
\hline \multicolumn{6}{|l|}{ Cognitive preference } \\
\hline $\begin{array}{l}\text { Perception of the } \\
\text { environment }\end{array}$ & $\begin{array}{l}\text { The SLCP helps improve the ecological environment: } \\
\text { strongly disagree }=1 \text {, disagree }=2 \text {, no opinion }=3 \text {, agree }=4 \text {, } \\
\text { strongly agree }=5\end{array}$ & 2.263 & 0.921 & 1 & 5 \\
\hline Perception of income & $\begin{array}{c}\text { The SLCP helps improve household income: strongly } \\
\text { disagree }=1 \text {, disagree }=2 \text {, no opinion }=3 \text {, agree }=4 \text {, strongly } \\
\text { agree }=5\end{array}$ & 2.667 & 1.192 & 1 & 5 \\
\hline $\begin{array}{l}\text { Perception of property } \\
\text { rights }\end{array}$ & $\begin{array}{c}\text { Management and conservation of the converted land each } \\
\text { year (times): } 0 \sim 20=1,20 \sim 40=2,40 \sim 60=3,60 \sim 80=4, \\
>80=5\end{array}$ & 1.782 & 1.216 & 1 & 5 \\
\hline \multicolumn{6}{|c|}{ Land plot characteristics } \\
\hline Quality of the land plot & $\begin{array}{l}\text { Soil quality: very bad }=1, \operatorname{bad}=2, \text { medium }=3 \text {, } \operatorname{good}=2 \text {, very } \\
\qquad \operatorname{good}=5\end{array}$ & 2.512 & 1.384 & 1 & 5 \\
\hline $\begin{array}{l}\text { Income of the land plot } \\
\text { before conversion }\end{array}$ & Net income of the land plot before conversion (yuan/mu) & 309.117 & 134.714 & 50 & 680 \\
\hline Slope of the land plot & $\begin{array}{l}\text { Slope of the land plot: flat slope }\left(0^{\circ} \sim 5^{\circ}\right)=1 \text {, gentle slope } \\
\left(6^{\circ} \sim 15^{\circ}\right)=2 \text {, moderate slope }\left(16^{\circ} \sim 25^{\circ}\right)=3 \text {, strong slope } \\
\qquad\left(26^{\circ} \sim 35^{\circ}\right)=4 \text {, very strong slope }\left(>35^{\circ}\right)=5\end{array}$ & 1.962 & 1.158 & 1 & 5 \\
\hline \multicolumn{6}{|l|}{ Control variables } \\
\hline Low-income household & Low-income household: yes $=1$, no $=0$ & 0.245 & 0.431 & 0 & 1 \\
\hline $\begin{array}{l}\text { Age of the head of } \\
\text { household }\end{array}$ & Actual age of the head of household (years) & 54.731 & 8.457 & 25 & 70 \\
\hline $\begin{array}{l}\text { Health status of the } \\
\text { head of household }\end{array}$ & Good $=1$, medium $=2$, bad $=3$ & 1.651 & 0.780 & 1 & 3 \\
\hline $\begin{array}{l}\text { Education of the head } \\
\text { of household }\end{array}$ & $\begin{array}{l}\text { Illiterate }=0 \text {, primary }=1 \text {, junior high }=2 \text {, secondary and } \\
\text { senior high }=3 \text {, junior college }=4 \text {, college and above }=5\end{array}$ & 2.645 & 0.764 & 1 & 5 \\
\hline $\begin{array}{l}\text { Political status of the } \\
\text { head of household }\end{array}$ & A party member or not: Yes $=1, \mathrm{No}=0$ & 0.139 & 0.346 & 0 & 1 \\
\hline Household labour & $\begin{array}{l}\text { Household labour within the } 18-60 \text { age range }=1 \text {, household } \\
\text { labour below } 18 \text { and above } 60=0.5 \text {, other cases }=0\end{array}$ & 1.961 & 1.095 & 0 & 5 \\
\hline $\begin{array}{l}\text { Per capita annual } \\
\text { income of household }\end{array}$ & $\begin{array}{c}\leq 5,000 \text { yuan }=1,5,000-10,000 \text { yuan }=2,10,000-20,000 \\
\text { yuan }=3,20,000-30,000 \text { yuan }=4,>30,000=5\end{array}$ & 11987.385 & 9006.979 & 633.667 & 65075 \\
\hline $\begin{array}{l}\text { Proportion of the SLCP } \\
\text { income }\end{array}$ & $\begin{array}{l}\text { Proportion of the income from the SLCP to the gross } \\
\text { household income }(\%): 0 \sim 5=1,5 \sim 10=2,10 \sim 15=3 \text {, } \\
\qquad 15 \sim 20=4,>20=5\end{array}$ & 1.647 & 1.290 & 1 & 5 \\
\hline Area of arable land & Area of arable land owned by the household: mu & 12.996 & 16.036 & 0 & 115 \\
\hline Area of converted land & The area of converted land owned by the household: mu & 5.268 & 5.278 & 0.5 & 46 \\
\hline \multicolumn{6}{|l|}{ Identification variable } \\
\hline $\begin{array}{l}\text { Proportion of SLCP } \\
\text { households }\end{array}$ & $\begin{array}{l}\text { Proportion of households participating in the SLCP to the } \\
\text { total number of households in the village (\%) }\end{array}$ & 0.364 & 0.029 & 0.269 & 0.427 \\
\hline
\end{tabular}


(1) Risk preference: Although only investment risk significantly affects the probability of peasant households' willingness to participate in the conservation auction, both planting risk and investment risk are positively correlated with peasant households' bid prices at 5\% significance level. This suggests that more risky peasant households are more willing to participate in conservation auctions and choose higher bid prices at the cost of reducing the probability of winning the bid.

(2) Social capital: Social prestige is positively correlated with peasant households' willingness to make a bid in conservation auctions at 5\% significance level, which indicates village cadres are more willing than common peasant households to accept the policy design of taking conservation auctions as a means of ecocompensation payment; social participation has a positive impact on peasant households' bid prices at $5 \%$ significance level, which suggests that rural capable people who participate more in social activities are willing to achieve higher bid prices by making use of the resources and information in hand.

(3) Cognitive preference: The perception of the environment, income, and property rights, passing the $5 \%$ level, $10 \%$ level, and 5\% level significance test, respectively, is positively correlated with peasant households' bid prices, which indicates that peasant households' perception of the ecological and economic benefits of the SLCP significantly promotes their bid prices in the conversation auction and that peasant households are more willing to choose relatively high bid prices when engaging more in the management and conservation of land plots under conversion to forests due to the influence of their perception of property rights.

(4) Land plot characteristics: As an indicator with dual attributes of generating both ecological and economic profits attributes, slope, is negatively correlated with peasant households' bid prices at 5\% significance level, which indicates the stronger the slope of an SLCP land plot is, the less income it generates from planting before the implementation of the SLCP and the lower bid prices peasant households tend to offer when considering its opportunity costs.

(5) Control variables: The age of the head of household has a significantly negative impact on a peasant household's willingness to bid and bid prices, passing the $5 \%$ level and $1 \%$ level significance test, respectively. That suggests, with their ages growing and out of consideration for stable income, the peasants tend to lose their enthusiasm for participating in conservation auctions and choose relatively low bid prices for higher probabilities of winning the bid. The health and political status of the head of household are positively correlated with his willingness to bid, passing the $5 \%$ level significance test. The results indicate that a good health is the basic guarantee of peasants' participation in bid auctions and fulfillment of auction contracts and that peasant households with Party members are more active in participating in conservation auctions. The area of arable land has a negative impact on peasant households' willingness to bid but a positive impact on their bid prices, which suggests SLCP peasant households with rich arable land resources are not very willing to participate in conservation auctions but they are driven by economies of scale to choose relatively high bid prices.

(6) Identification variables: The proportion of SLCP peasant households has a positive relationship with peasant households' willingness to bid, passing the $1 \%$ level significance test, which indicates peasant households in the villages with higher proportions of households engaged in the SLCP are more willing to participate in conservation auctions. But this ratio has no significant impact on bid prices, which suggests the identification variable has been selected appropriately.

\subsection{Suggestions on Optimizing Ecological Compensation.} Strengthen the information publicity of ecological compensation policy, make the incentive policy open and transparent, reduce farmers' awareness of the high risk of ecological compensation, improve farmers' enthusiasm for participation through incentive policy, set up property right knowledge lectures, and enhance farmers' awareness of property rights. At the same time, it is best to establish ecological compensation projects in the surrounding areas, so that farmers can understand the relevant information of ecological compensation in the surrounding areas, deepen their understanding of ecological compensation, and enhance their willingness to participate in ecological compensation.

The diversification of farmers' income sources will also promote the implementation of ecological compensation policy. With the development of information society, farmers' demand for labour transfer is increasing day by day. They often struggle between continuing farming and going out to work. Generally speaking, the higher the education level, the faster the ability to accept new things. Therefore, for farmers with higher education, their vision and thinking are also broader. They are more able to look at the ecological compensation policy from an objective perspective, which can often play a role model and drive other farmers to participate. At the same time, the government should increase support for sideline and migrant work other than farming, based on the necessary help of farmers, which is also conducive to increasing farmers' confidence in the government, so as to improve farmers' participation in ecological compensation policies. In the process of implementing the ecological compensation policy, we can also vigorously support the development of organic agriculture, improve the protection of the ecological environment, develop low-carbon organic agriculture, fundamentally 
TABLE 3: The estimated results of Heckman sample selection model.

\begin{tabular}{|c|c|c|c|c|c|c|}
\hline & & obit regression & & & LS regression & \\
\hline & Coefficient & Standard error & $z$-score & Coefficient & Standard error & $t$-value \\
\hline $\begin{array}{l}\text { Core explanatory variables } \\
\text { Risk preference }\end{array}$ & & & & & & \\
\hline Planting risk & 0.096 & 0.087 & 1.11 & $15.251^{* *}$ & 5.168 & 2.95 \\
\hline Investment risk & $0.214^{* *}$ & 0.108 & 1.97 & $20.489^{* * *}$ & 5.769 & 3.55 \\
\hline Social capital & & & & & & \\
\hline Social prestige & $1.526^{* *}$ & 0.543 & 2.81 & 30.771 & 19.256 & 1.60 \\
\hline Social network & -0.055 & 0.061 & -0.91 & 1.583 & 3.479 & 0.45 \\
\hline Social participation & 0.139 & 0.092 & 1.51 & $9.837^{* *}$ & 4.914 & 2.00 \\
\hline Cognitive preference & & & & & & \\
\hline Perception of the environment & 0.071 & 0.106 & 0.67 & $16.958^{* *}$ & 5.982 & 2.83 \\
\hline Perception of income & -0.015 & 0.082 & -0.18 & $8.040^{*}$ & 4.824 & 1.67 \\
\hline Perception of property rights & 0.075 & 0.089 & 0.84 & $29.016^{* * *}$ & 4.304 & 6.74 \\
\hline Land plot characteristics & & & & & & \\
\hline Slope & 0.037 & 0.076 & 0.49 & $-10.550^{* *}$ & 4.795 & -2.20 \\
\hline Control variables & & & & & & \\
\hline Low-income households & -0.150 & 0.191 & -0.79 & -4.367 & 12.808 & -0.34 \\
\hline Age of the head of household & $-0.043^{* *}$ & 0.013 & -3.27 & $-4.628^{* * *}$ & 0.668 & -6.93 \\
\hline Health of the head of household & $-0.246^{* *}$ & 0.117 & -2.09 & -6.780 & 8.182 & -0.83 \\
\hline Education of the head of household & -0.085 & 0.123 & -0.69 & -3.217 & 7.043 & -0.46 \\
\hline Political status of the head of household & $0.767^{* *}$ & 0.296 & -2.59 & -6.502 & 18.263 & -0.36 \\
\hline Household labour & 0.035 & 0.082 & 0.43 & -4.351 & 4.978 & -0.87 \\
\hline Proportion of SLCP income & 0.083 & 0.097 & 0.86 & 0.856 & 4.789 & 0.18 \\
\hline Area of arable land & $-0.015^{* *}$ & 0.007 & -2.25 & $0.800^{* *}$ & 0.343 & 2.34 \\
\hline Area of converted land & 0.002 & 0.023 & 0.09 & 0.932 & 1.005 & 0.93 \\
\hline Identification variables & & & & & & \\
\hline Proportion of SLCP peasant households & $31.794^{* * *}$ & 4.832 & 6.58 & & & \\
\hline Inverse Mills ratio $(\lambda)$ & & & & $35.716^{*}$ & 21.327 & 1.67 \\
\hline Constant variable & $-10.625^{* * *}$ & 2.368 & -4.49 & $321.800^{* * *}$ & 82.631 & 3.89 \\
\hline
\end{tabular}

${ }^{*},{ }^{* *}$, and ${ }^{* * *}$ represent the estimated coefficient is statistically significant at the $1 \%$ level, at the $5 \%$ level, and at the $10 \%$ level, respectively.

improve the agricultural economic benefits, and promote the sustainable development of economy and society through the ecological compensation policy.

\section{Conclusion and Discussion}

Our results show that the average bid price of peasant households in the ecologically fragile region in northwest Liaoning for the Sloping Land Conversion Programme is annually 274.5 yuan per mu, close to the net income of 309.1 yuan per mu before the SLCP and also close to the compensation standard of 300 yuan per mu for the new-round SLCP [32]. It is 3.05 times the subsidies for the consolidation period of the first-round SLCP. As the important subjects to implement and manage the SLCP, $78.6 \%$ of peasant households are willing to participate in conversation auctions, which indicates means of compensation based on the willingness of peasant households are easier to be accepted, among them, the query function constructed by cloud computing provides convenience for farmers to obtain information to a large extent. Risk preference and social capital have positive effect on peasant households' willingness to bid in conservation auctions as well as on their bid prices; cognitive preference has positive effect on bid prices in conservation auctions; land plot characteristics have negative effect on bid prices in conservation auctions; of the factors of family endowment, the age of the head of household has significantly negative effect on peasant households' willingness to bid and on their bid prices, the health and political status of the head of household has positive effect on the peasant household's willingness to bid, and the area of arable land has negative effect on peasant households' willingness to bid but positive effect on their bid prices. According to these findings, it is advised to improve ecocompensation policy design following peasant households' willingness, lower SLCP peasant households' risk perception, give play to the leading and exemplary role of the village Party branch, the village committee, village cadres, and active management participants, strengthen peasant households' perception that the SLCP helps improve the environment and income, and encourage peasant households' management and conversion of the converted land through the design of conservation auction contracts.

This paper uses protective auction mechanism to solve the problem of information asymmetry. At the same time, it is innovative to use cloud computing to establish a database, realize information query, facilitate farmers, and establish an ecological compensation standard based on farmers' real opportunity cost. However, this paper only selects the information of 453 farmers in three national pilot counties in western Liaoning as the data sample, which has limitations. Therefore, in the next research, more data will be used for 
statistics and supplemented with more sample data for research and analysis, so as to make the application of distribution auction algorithm in the operation of ecological compensation more persuasive and referential, make the ecological compensation standard based on farmers' protection auction mechanism more perfect, and lay a good foundation for extensive promotion in the future.

\section{Data Availability}

Data sharing is not applicable to this article as no datasets were generated or analysed during the current study.

\section{Conflicts of Interest}

The authors declare no potential conflicts of interest with respect to the research, authorship, and/or publication of this article.

\section{Acknowledgments}

This paper was supported by General Projects of National Social Science Fund in 2020 "Study on the impact of collective forest land use control on the welfare of farmers and ecological compensation system in Nature reserves" (20BGL173), China National Natural Science Foundation "Research on Ecological Public Welfare Forest Compensation Mechanism from the Perspective of Farmer Behavior Response: Based on the Empirical Study of Framed Field Experiments and Follow-up Investigation" (72073029), Soft Science Research Project of Department of Science and Technology of Shaanxi Province (2021KRM040), and Key Scientific Research Project of Education Department of Shaanxi Province (20JT049).

\section{References}

[1] S. Wunder, Payments for Environmental Services: Some Nuts Andbolts, CIFOR Occasional Paper, Center for International Forestry Research, vol. 42, pp. 3-8, Jakarta, Indonesia, 2005.

[2] L. Di, H. Zhentong, and J. Leshan, "A review of the analysis framework of ecological conservation compensation," Acta Ecologica Sinica, vol. 38, no. 2, pp. 380-392, 2018.

[3] G. Huimin and W. Wukui, "Spatial distribution of compensation funds for the conversion of farmland to forests based on opportunity costs: taking Zhangjiakou as an example," Science of Soil and Water Conservation, vol. 13, no. 4, pp. 137-143, 2015.

[4] M. Y. Hou, S. B. Yao, Y. J. Deng et al., "Spatial-temporal evolution pattern and differentiation of ecological service value in Yan'an city at the grid scale based on sloping land conversion program," Journal of Natural Resources, vol. 34, no. 3, pp. 539-552, 2019.

[5] Wang, H. G. Hao, R. X. Zhai, and S. F. Liu, "Determinants of farm households'ecological compensation expectation to the grain for green project: an empirical analysis based on Haba Lake National Nature Reserve and Liupanshan Mountain National Nature Reserve," Journal of Arid Land Resources and Environment, vol. 31, no. 8, pp. 69-75, 2017.

[6] P. Jie, C. Zongling, and J. Leshan, "Research on the willingness of peasant households with heterogeneous resources to be compensated for the conversion of farmland to forests and its influencing factors-based on the survey data of 2 counties in Yunnan province," Rural Economy, vol. 38, no. 1, pp. 104-111, 2020.

[7] H. Hongyun and Y. Yonghong, "Research on ecological compensation for the conversion of farmland to forests-cost Basis, acceptance willingness or ecological value standards," Issues in Agricultural Economic, vol. 35, no. 4, pp. 64-72, 2014.

[8] Q. Yanhong and K. Muyi, "The compensation standards for peasant households' participation in ecological construction based on opportunity costs: taking peasant households' participation in the Conversion of farmland to forests in Wuqi County as an example," China Population, Resources and Environment, vol. 21, no. 12, pp. 65-68, 2011.

[9] S. Hanyu and L. Guoping, "The impact of ecological benefits and economic rents on the willingness to be compensated for ecological conservation," China Population, Resources and Environment, vol. 28, no. 11, pp. 91-101, 2018.

[10] C. Xie, K. Zhang, W. Peng et al., "Policy trends and demand during the alternating phase of conversion of cropland to forests program-the main results of 2014 social economic $\mathrm{M} \& \mathrm{E}$ of conversion of cropland to forests program," Forestry Economics, vol. 37, no. 6, pp. 16-22.

[11] P. J. Ferraro, "Asymmetric information and contract design for payments for environmental services," Ecological Economics, vol. 65, no. 4, pp. 810-821, 2008.

[12] L. U. Latacz and H. C. Van der, "Auctioning conservation contracts: a theoretical analysis and an application," American Journal of Agricultural Economics, vol. 79, no. 2, pp. 407-418, 1997.

[13] G. Stoneham, V. Chaudhri, A. Ha, and L. Strappazzon, "Auctions for conservation contracts: an empirical examination of Victoria's BushTender trial," The Australian Journal of Agricultural and Resource Economics, vol. 47, no. 4, pp. 477-500, 2003.

[14] R. Claassen, A. Cattaneo, and R. Johansson, "Cost-effective design of agri-environmental payment programs: U.S. experience in theory and practice," Ecological Economics, vol. 65, no. 4, pp. 737-752, 2008.

[15] B. K. Jack, B. Leimona, and P. J. Ferraro, “A revealed preference approach to estimating supply curves for ecosystem services: use of auctions to set payments for soil erosion control in Indonesia," Conservation Biology, vol. 23, no. 2, pp. 359-367, 2010.

[16] K. Kawasaki, T. Fujie, K. Koito, N. Inoue, and H. Sasaki, "Conservation auctions and compliance: theory and evidence from laboratory experiments," Environmental and Resource Economics, vol. 52, no. 2, pp. 157-179, 2012.

[17] B. Leimona, B. K. Jack, B. Lusiana, and R. Pasha, "Designing a procurement auction for reducing sedimentation: a field experiment in Indonesia," EEPSEA Research Report, vol. 113, no. 6, pp. 1265-1267, 2010.

[18] D. Xiaohong and X. Zhongmin, "The application of auctions with participants having different risk preferences to ecological compensation: taking the conversion of grazing land to grassland in Sunan County as an example," Systems Engineering-Theory and Practice, vol. 32, no. 11, pp. 2412-2418, 2012.

[19] X. Wang, J. Bennett, J. Xu, and H. Zhang, "An auction scheme for land use change in Sichuan Province, China," Journal of Environmental Planning and Management, vol. 55, no. 10, pp. 1269-1288, 2012.

[20] Z. Liu, J. Xu, X. Yang, Q. Tu, N. Hanley, and A. Kontoleon, "Performance of agglomeration bonuses in conservation auctions: lessons from a framed field experiment," 
Environmental and Resource Economics, vol. 73, no. 3, pp. 843-869, 2019.

[21] S. G. M. Schilizzi, "An overview of laboratory research on conservation auctions," Land Use Policy, vol. 63, pp. 572-583, 2017.

[22] Z. Chaohui, "An analysis of the influencing factors of peasant households' risk perception in the new round of conversion of farmland to forests: based on survey data in Aksu, Xinjiang," Resources Science, vol. 40, no. 7, pp. 1387-1396, 2018.

[23] İ. Unay-Gailhard and Š. Bojnec, "Sustainable participation behaviour in agri-environmental measures," Journal of Cleaner Production, vol. 138, no. 1, pp. 47-58, 2016.

[24] S. Hengtong, W. Zhengyu, and Y. Liang, "The impact of ecological perceptionon peasant households' behavior in conversion of farmland to forests-based on the theory of planned behavior and multi-group structural equation model," China Land Science, vol. 33, no. 3, pp. 42-49, 2019.

[25] T. N. Cason, L. Gangadharan, and C. Duke, "A laboratory study of auctions for reducing non-point source pollution," Journal of Environmental Economics and Management, vol. 46, no. 3, pp. 446-471, 2003.

[26] T. W. Schultz, Transforming Traditional Agriculture, Translated by Liang Xiaoming, Commercial Press, Beijing, China, 1987.

[27] A. Y. Banana and W. Gombya-Ssembajjwe, "Successful forest management: the importance of security of tenure and rule enforcement in Ugandan forests," People and Forest, vol. 30, no. 7, pp. 87-98, 2000.

[28] J. Dijk, E. Ansink, and D. P. Van Soest, "Conservation auctions, collusion and the endowment effect," SSRN Electronic Journal, no. 93, pp. 1-20, 2018.

[29] A. Portes, "Social capital: its origins and applications in modern sociology," Annual Review of Sociology, vol. 24, no. 24, pp. 1-24, 1998.

[30] C. A. Holt and S. K. Laury, "Risk aversion and incentive effects," The American Economic Review, vol. 92, no. 5, pp. 1644-1655, 2002.

[31] G. J. Kits, The Impacts of Social Capital andLeadership on Conservation Auctions, University of Alberta, Canada, 2011.

[32] National Forestry and Grassland Administration, China's Conversion of Farmland to Forests and Grasses for Twenty Years (1999-2019), 2020.

[33] U. Latacz-lohmann and S. Schilizzi, "Auctions for conservation contracts: a review of the theoretical and empirical literature," Inorganic Chemistry, vol. 49, no. 3, pp. 943-951, 2005.

[34] B. K. Jack, "Private information and the allocation of land use subsidies in Malawi," American Economic Journal: Applied Economics, vol. 5, no. 3, pp. 113-135, 2013.

[35] K. D. Messer, P. J. Ferraro, and W. Allen, "Behavioral nudges in competitive environments: a field experiment examining defaults and social comparisons in a conservation contract auction," in Proceedings of the AAEA \&WAEA Joint Annual Meeting, Anaheim, CA, USA, July 2015.

[36] T. N. Cason and L. Gangadharan, "Auction design for voluntary conservation programs," American Journal of Agricultural Economics, vol. 86, no. 5, 2004.

[37] S. Schilizzi and U. Latacz-Lohmann, "Evaluating conservation auctions with unknown bidder costs: the Scottish fishing vessel decommissioning program," Land Economics, vol. 88, no. 4, pp. 658-673, 2012.

[38] J. J. Heckman, "Sample selection bias as a specification error," Econometrica, vol. 47, no. 1, pp. 153-161, 1979.
[39] J. M. E. Pennings and R. Leuthold, "The role of peasant households' behavioral attitudes and heterogeneity in futures contractsusage," American Journal of Agricultural Economics, vol. 82, no. 4, pp. 908-919, 2000.

[40] P. L. Liao, X. J. Li, M. L. Bi, and X. L. Xia, "Impact of family endowment and cognitive preferences on farmers' willingness to manage, maintain and invest in the achievement of grain for green project-based on the survey data of 554 households in Shan-Gan-Ning region," Journal of Arid Land Resources and Environment, vol. 33, no. 5, pp. 47-53, 2019.

[41] L. Qian and W. Xin, "An overview and analysis framework of social capital," Commercial Research, no. 2, pp. 141-145, 2012.

[42] N. Kosoy, M. Martinez-Tuna, R. Muradian, and J. MartinezAlier, "Payments for environmental services in watersheds: insights from a comparative study ofthree cases in Central America," Ecological Economics, vol. 61, no. 2/3, pp. 446-455, 2007. 